\title{
Editorial
}

\section{The Social Psychology of Religion: Current Research Themes}

\author{
ADRIAN COYLE ${ }^{1}$ and EVANTHIA LYONS ${ }^{2}$ \\ ${ }^{1}$ Department of Psychology, University of Surrey, UK \\ ${ }^{2}$ School of Psychology, Queen's University, Belfast, UK
}

\section{Published as:}

Coyle, A., \& Lyons, E. (2011). The social psychology of religion: Current research themes. Journal of Community \& Applied Social Psychology, 21(6), 461-467.

Correspondence to: Adrian Coyle, Department of Psychology, University of Surrey,

Guildford, Surrey GU2 7XH, United Kingdom. Phone: +44 (0)1483 686896. Email:

A.Coyle@surrey.ac.uk

Word count: 3390 (including acknowledgements and references) 


\section{INTRODUCTION}

In the Western world in recent years, concerns about the (potential and actual) social and political implications of the rise of 'fundamentalist Islam' have seen a range of questions being raised and culturally debated concerning the social risk/value of Islam in particular and religion in general and its role within the state. These debates have often become polarized, with anti-religious definitive positions attracting considerable attention, most notably in the form of Richard Dawkins' (2006) best-selling book, The God Delusion. This book (and those embodying the same outlook published around the same time and subsequently) represents belief in God as irrational and constructs religion as having a corrupting influence on values and ethics and as having lain at the heart of a variety of social evils across history. This body of literature has inspired critical responses from religious and, more frequently, specifically Christian writers (for example, see Beattie, 2007; Ward, 2008).

Some of the questions raised in these debates invoke standard social psychological concerns such as identity, group processes and intergroup relations, with a focus on trying to understand what fosters pro-social and anti-social behaviours that appear to be motivated and justified by religion. These questions have been studied in relation to religion by scholars within social psychology and within the psychology and sociology of religion, even if the complexity of the issues identified in this research has not always been reflected in cultural debates. For example, the Dawkins-related and other literature has sought to defend the Western liberal 'moral zeitgeist' against what it has constructed as the threat posed by inherently prejudiced (fundamentalist) religion. However, social psychological research on prejudice and religion suggests a complex relationship between the two, with religion potentially promoting prejudice and also potentially attenuating it, depending upon contextual and mediating factors (see 
Hunsberger \& Jackson, 2005). More generally, it has been proposed that to understand religiously-based social behaviours, it is necessary to see them as regulated by a set of personal, social and cognitive systems of meanings, with these systems interacting with each other and with religion (Paloutzian \& Silberman, 2003). Such viewpoints are quite different from the simplistic, decontextualized understandings of religious behaviours that are sometimes seen within current cultural debates.

It therefore seems an opportune time to review some of the themes that are currently being explored within research that can be located under the heading of 'the social psychology of religion'. However, exactly what constitutes 'the social psychology of religion' is open to debate, as is the nature of broader domain, 'the psychology of religion'. The psychology of religion emerged as a distinct sub-discipline in the USA in the latter part of the twentieth century (and really only began to gather momentum in Britain in the 1990s), aiming to approach religion from the standpoint of psychology without making assumptions about particular religious truths and values. The historian of the psychology of religion, Jacob Belzen (2001), noted that a distinction might be drawn between work that aims to obtain psychological insight into the particularity of religion and work that aims primarily to test psychological theory, with religious contexts simply being one of several testing settings. Depending upon how purist or liberal one's perspective, the former could be regarded as the 'genuine' psychology of religion or both could be seen as legitimately contributing to the discipline. It was always intended that this special issue would adopt a liberal, inclusive approach to the social psychology of religion, which is fortunate because the constitutive papers could be said to embody aspects of both versions, with an additional recurrent emphasis on using social psychology to identify potentially useful responses to social challenges relevant to religion or to issue caveats about possible responses. 
An even more fundamental matter of debate concerns the meaning of 'religion'. There is a growing awareness that the frequently-encountered Western understanding of religion as a personality trait-like property of the individual is culturally and historically specific and that the term is more properly understood as designating a socio-culturally constituted 'multifarious and multiplex phenomenon' (Belzen, 2001, p. 46). This has led Belzen (2010) to argue for conceptualizing the psychology of religion in terms of 'cultural psychology'. Whether or not one accepts this particular case, it has been noted by writers on the psychology of religion and spirituality that religion can be defined as inherently social (Donahue \& Nielsen, 2005, p. 275), which renders a social psychological perspective an eminently suitable vantage point from which to study religion (the value of a community psychology perspective has also been advanced, particularly in relation to spirituality: Hill, 2000). A related definitional question concerns the inclusion or exclusion of 'spirituality' in/from the foci of the psychology of religion. This has been hotly debated within the domain (see Pargament, 1999) as it has attempted to develop a useful response to the shift away from institutional, organized religion and towards less formal, more personal 'spirituality' in the Western post-Christian world (see Heelas \& Woodhead, 2005; Tacey, 2004). Given the definitional diversity that characterizes writing on spirituality (for example, see Zinnbauer et al., 1997), the decision was taken to restrict this special issue to a consideration of work on the social psychology of religion.

\section{TOPICS AND THEMES IN THE SOCIAL PSYCHOLOGY OF RELIGION}


When we were planning this special issue, we were unsure of the extent of response that would be elicited by a call for abstracts for potential papers. We were delighted to receive 27 abstracts, mostly from researchers and writers in countries across Europe (Austria, Belgium, Croatia, France, Germany, Greece, Italy, Malta, the Netherlands and the United Kingdom) but also from the USA, Canada, Australia and New Zealand. Social psychological work on religion is not only being conducted in disparate locations but also with diverse foci. Although we identified some potential foci in our call for papers, the topics addressed by the abstracts went well beyond these, covering religious and particularly Islamic identity; religious-inspired terrorism; religious fundamentalism; religious stereotypes, prejudice and discrimination; religious minorities and acculturation; religious inter-group and intra-group conflict; associations between religiousness and authoritarianism, guilt and shame; religion and attributions of agency; religion and conformity; inter-faith relations; and religion and Terror Management Theory. The only surprising absence from this list was religious conversion and related phenomena which have been fairly extensively researched, albeit not routinely from a social psychological perspective (but one paper in this special issue - by Grigoropoulou and Chryssochoou - considers the implications of minority group members adopting the majority's religion for how the former are perceived by the majority). This diversity of topics demonstrates the broad scope of the social psychology of religion, reinforcing a similar message communicated by the range of papers from social and personality psychology perspectives that appeared in a recent special issue of Personality and Social Psychology Review on why religiosity persists (Sedikides, 2010).

Fascinating though many of the abstracts that we received were, practical constraints meant that ultimately we have only been able to present five papers in this special issue. These are all from European research contexts and reflect something of the diversity of European social psychology in terms of epistemology, methodology and theory. 
Unsurprisingly, four of the five papers are (at least in part) concerned with representations of Islam and Islamic identities. As Chris McVittie and colleagues note in their paper, 'Often Islam is presented as a religion that, in some respects at least, is essentially antithetical to Western understandings and practices', which raises a host of social psychological questions about Islamic identities and communities in European contexts.

The paper that opens the special issue is from Sue Widdicombe who helpfully comments on the relationship between psychology and religion before introducing social constructionist, discursive research approaches. Her adoption of a discursive psychological approach to Syrian Muslims' and Christians' claims about being religious constitutes a novel contribution to the study of religiousness in the sense of 'what it means to be religious'. Through a close analysis of extracts from a large qualitative data set, she examines the diverse ways in which participants responded to the question 'Are you religious?', revealing the interactional business being transacted in responses to questions about 'being religious'. Widdicombe points to the diversity of meanings accorded to the same linguistic features, such as religious attributes, depending on the different functions those features perform in different contexts. She uses this reading to question the appropriateness of pre-defining aspects of 'being religious' within decontextualized measures of religiousness in the psychology of religion and suggests that such measures cannot capture the subtle, inferential aspects of how people position themselves in relation to 'religiousness'. This is an important consideration for the discipline, particularly in work on categories that researchers may be tempted to treat in stark terms, such as 'fundamentalism' and 'political Islam'.

In the second paper, Vassilis Saroglou, Vincent Yzerbyt and Cécile Kaschten consider the meta-stereotypes that (mostly Christian) religious believers and non-believers hold about each other in a country with a predominant Catholic tradition and they link these to existing literature on religion and personality. We are delighted to be able to present a paper from 
these contributors as they hail from one of the few specialist centres for the psychology of religion in Europe at the Université Catholique de Louvain in Belgium.

Among the findings reported in this paper, believers and non-believers seemed to share the meta-stereotype that the other group saw them as respectively high versus low in prosociality, conservatism and self-control-related traits. With the exception of prosociality, they may be happy with these perceptions that are presumably valued differently within each group. At the same time, believers seemed to ignore the fact that non-believers saw them as dogmatic, and non-believers often seemed to meta-stereotypically exaggerate their differences in comparison to how believers actually saw them. Most meta-perceptions that Saroglou and colleagues found accord with the literatures on religiousness, personality, values and behaviours and on religious stereotypes. This allows the researchers to conclude that, at least to some extent, there is some broad accuracy in the meta-perceptions held by the groups of believers and non-believers. However, they go beyond merely noting this and pose questions for future research about the reasons for this accuracy, wondering 'does this accuracy reflect personal experience and thus generalized knowledge of the real personality of believers and non-believers or does it simply reflect shared implicit theories and ideologies?'

In their reflections upon other findings, the nature of the sample of believers as a majority group and non-believers as a minority group in the Belgian context becomes relevant. The processes that are suggested to operate in relation to these statuses would be different in a context where believers were a minority and non-believers a majority. Yet, given that people may be reluctant to self-identify explicitly as non-believers and may selfpresent as believers in a qualified way and given Davie's (1994) contention about 'believing without belonging', we may need to inquire further into what self-identifications as a 'believer' or 'non-believer' mean in practice in people's lives. 
The paper by Nikolitsa Grigoropoulou and Xenia Chryssochoou is also concerned with perceptions held by one group about (an)other group(s) in Greece. As noted earlier, using an experimental research design, they explored Greek-Orthodox students' responses to a fictitious character who was variously described as belonging to a religious minority with Greek citizenship or to an ethnically and religiously different immigrant group and who decided either to adopt the majority's religion or to maintain his religious position. Findings indicated that when the character decided to adopt the majority's religion, he was considered more 'Greek'. Curiously, though, participants showed greater agreement with the character's decision when he decided to maintain his original religious position: religious assimilation did not seem to be the majority's preferred strategy for minorities. The researchers call for further investigation of the reasons for this.

Perhaps the most startling finding reported by any of the papers concerned the majority's response to the character when he was described as Albanian Muslim or atheist and as having decided to become Greek-Orthodox. When described as belonging to other minority groups, the character was perceived as less identified with the minority ingroup after adopting the majority religion but when described as Albanian, he was deemed to remain highly identified with the minority group after conversion. Although the social response to the Albanian minority in Greece could be seen as context-specific, on the basis of their range of findings the authors suggest that the acculturation strategy recommended to and adopted by minorities may not be what matters in how they are perceived by the majority, even when the strategy is as extreme as adopting the majority's religion. Rather, for minorities that are deemed particularly threatening for whatever reason, it may be that 'in reality what matters is "who they are"".

Muslim identities are examined specifically in the final two papers. Using discourse analysis, Chris McVittie, Andy McKinlay and Rahul Sambaraju scrutinized media interviews 
with leaders of the Islamist Hamas movement concerning Islam within the Gaza strip in Palestine and noted how different forms of Muslim identities are mobilized by speakers in talk about intergroup relations. In their discussion of the nature and implications of a proposed Islamic state, speakers address the relationship between religion and civic society/politics, thus connecting to contemporary debates within the Western world. Through their close analysis of data, McVittie and colleagues demonstrate the standard social constructionist understanding of identities as tied up with local interactional contexts and concerns, such as the deflection of competing constructions of an Islamic state. To this extent, the paper could be said to exemplify one branch of Belzen's (2001) dual account of the domain in which researchers' primary focus is on more general psychological phenomena (in this case, understood broadly), with the religious aspect of their work being more contextual rather than a central concern. The other discourse analytic paper by Sue Widdicombe seems to strike a different balance in that it is thoroughly social constructionist whilst placing religion at the centre of its concerns around the negotiation of claims to be religious.

That same emphasis can be seen in the final paper in which Nick Hopkins explores religion, identity and 'social capital' (the connections among individuals and groups). He reports some qualitative analysis but his contribution is primarily a commentary within a critical social psychology perspective, albeit a more integrative one than the discourse analytic, non-cognitivist approach that characterizes much critical social psychology. Emphasizing the contingency of identity in relation to context (thereby echoing the analyses of Widdicombe and of McVittie and colleagues) and thus the wider social processes that any meaningful examination of identity must take into account, he illustrates these points through consideration of interview data relevant to Muslim identity in Britain and considers the implications of different constructions of Muslim identity for how social capital is produced. 
However, his paper does not simply explore theoretical questions but carries practical implications for social interventions with minority religious groups. For example, Hopkins characterizes inter-faith dialogue as a possible 'bridging' form of social capital, creating connections between religious groups. However, he notes that 'bonding' capital may need to be fostered within groups before they can engage in bridging activity without group identity being threatened by the possible highlighting of within-group diversity during dialogue (or during any other bridging activity).

\section{CONCLUSION}

It is important to acknowledge that the concerns explored by the papers in this special issue do not 'belong' to social psychology but have been examined from other disciplinary vantage points too, such as sociology, anthropology and politics. The social psychology of religion might profitably draw ideas from the study of religion in those disciplines to produce enriched understandings. Scholars in those disciplines might usefully reciprocate when exploring topics with social psychological relevance, such as religious identities, and/or social psychologists might draw research questions from relevant work in other disciplines and extend its analyses through the application of social psychological theories and concepts.

While academic exchange across disciplines is worthwhile for producing rich analyses, the evident potential across papers for using social psychology to identify informed and constructive responses to social challenges relevant to religion reminds us of the applied value of work in this area. For example, in its suggestion about the need to foster bonding 
capital within groups in preparation for bridging activities, Nick Hopkins' paper could be said to reach beyond social psychology and to carry potential for contributing fruitfully to the domain of practical theology and community interventions around inter-faith relations. Indeed, questions about meaningful engagement with the religious 'Other' that are relevant to inter-faith relations are raised and/or addressed across this special issue. It might thus be said that the papers underline the potential for fruitful dialogue and an exchange and integration of insights between social psychology, practical theology and other domains of community practice in relation to fostering constructive relations between religious groups (although Grigoropoulou and Chryssochoou's findings remind us of the challenges involved). Also, it is important to acknowledge that bringing (social) psychology and theology or religious bodies together as dialogue partners may not be easy owing to fundamental differences in ontological and epistemological assumptions and wariness about the scope of each party's interpretative entitlement (for example, see Ormerod, 2005). Ironically the processes that Hopkins highlights in his paper may need to be fostered among the disciplinary, professional and community bodies involved in trying to facilitate constructive relations between religious groups. 


\section{ACKNOWLEDGEMENTS}

We would like to acknowledge the invaluable assistance and understanding that we received from Sandra Schruijer and Flora Cornish in their editorial roles as we conceived this special issue and brought it to fruition. We would also like to express our sincere gratitude to all those who provided reviews of the papers that we received: Christopher Cohrs (Queen's University, Belfast); Joanna Collicutt (Ripon College Cuddesdon, Oxford); Mick Finlay (Anglia Ruskin University); Stephen Gibson (York St John University); Ralph Hood (University of Tennessee); Abigail Locke (University of Huddersfield); Patrick Martens (Queen's University, Belfast); Ola Musleh (Bethlehem University); Müjde Peker (Boğaziçi University, Turkey); Ralph Piedmont (Loyola University Maryland); Bernd Simon (Christian-Albrechts-University of Kiel); Clifford Stevenson (University of Limerick); Andrew Todd (Cardiff University); Karen Trew (Queen's University, Belfast); Chris Walton (Lancaster University); and Hanna Zagefka (Royal Holloway, University of London). 


\section{REFERENCES}

Beattie, T. (2007). The new atheists: The twilight of reason \& the war on religion. London: Darton, Longman \& Todd.

Belzen, J. A. (2001). The future is in the return: Back to cultural psychology of religion. In D. Jonte-Pace \& W. B. Parsons (Eds), Religion and psychology: Mapping the terrain. Contemporary dialogues, future prospects (pp.43-56). London: Routledge.

Belzen, J. A. (2010). Towards cultural psychology of religion: Principles, approaches, and applications. New York: Springer.

Davie, G. (1994). Religion in Britain since 1945: Believing without belonging. Oxford: Blackwell.

Dawkins, R. (2006). The God delusion. London: Bantam Press.

Donahue, M. J., \& Nielsen, M. E. (2005). Religion, attitudes, and social behaviour. In R. F. Paloutzian \& C. L. Park (Eds.), Handbook of the psychology of religion and spirituality (pp. 274-291). New York: The Guilford Press.

Heelas, P., \& Woodhead, L. (2005). The spiritual revolution: Why religion is giving way to spirituality. Oxford: Blackwell.

Hill, J. (2000). A rationale for the integration of spirituality into community psychology. Journal of Community Psychology, 28, 139-149.

Hunsberger, B., \& Jackson, L. M. (2005). Religion, meaning, and prejudice. Journal of Social Issues, 61, 807-826. 
Ormerod, N. (2005). A dialectic engagement with the social sciences in an ecclesiological context. Theological Studies, 66, 815-840.

Paloutzian, R. F., \& Silberman, I. (2003). Religion and the meaning of social behaviour: Concepts and issues. In P. H. M. P. Roelofsma, J. M. T. Corveleyn, \& J. W. van Saane (Eds.), One hundred years of psychology and religion: Issues and trends in a century long quest (pp. 155-167). Amsterdam: VU University Press.

Pargament, K. L. (1999). The psychology of religion and spirituality? Yes and no. International Journal for the Psychology of Religion, 9, 3-16.

Sedikides, C. (2010). Why does religiosity persist? Personality and Social Psychology Review, 14, 3-6.

Tacey, D. (2004). The spirituality revolution: The emergence of contemporary spirituality. Hove: Brunner-Routledge.

Ward, K. (2008). Why there almost certainly is a God: Doubting Dawkins. Oxford: Lion.

Zinnbauer, B. J., Pargament, K. I., Cole, B., Ryle, M. S., Butter, E. M., Belavich, T. G., Hipp, K. M., Scott, A. B., \& Kadar, J. L. (1997). Religion and spirituality: Unfuzzying the fuzzy. Journal for the Scientific Study of Religion, 36, 549-64. 